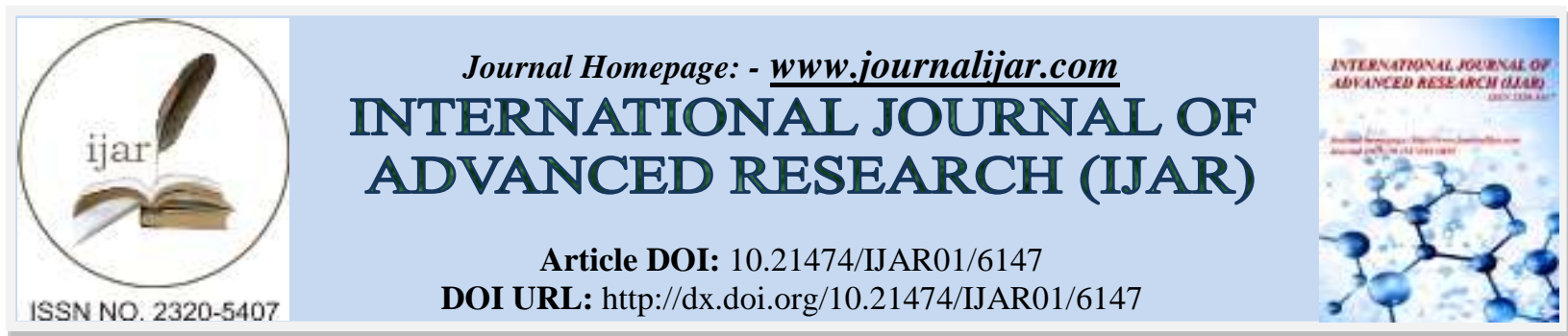

RESEARCH ARTICLE

\title{
ANALYSIS OF THE INFLUENCE OF ORGANIZATIONAL JUSTICE AND CONTROL BEHAVIOR TO MEMBERSHIP OF ORGANIZATIONAL MEMBERSHIP WITH QUALITY OF LEADERS AND EMPLOYEES RELATIONS AS INTERVENING VARIABLES.
}

Herman Ahmadi.

University of PGRI Madiun.

\section{Manuscript Info}

Manuscript History

Received: 23 October 2017

Final Accepted: 25 November 2017

Published: December 2017

Key words:-

Organizational citizen behavior, Organizational Justice, Span of control, Leader Member Exchange.

\section{Abstract}

Many factors exist within an organization that are involved and need attention. Factors such as financial factors, technology, information systems, production equipment, natural resources, and human resources. In a company or organization, human is a valuable asset, relationship leaders and employees is seen as an important factor in discussing the phenomenon of leadership. The importance of human role in determining the success of an institution, both private sector institutions and the public sector with the ability to create value based on its people, not through the utilization of natural resources and technology but more concerned with the quality of work of human resources.

The purpose of this study is to analyze the various factors that affect the organization membership (Oganizational citizenship Behavior, OCB) employees BCA Regional Office Madiun, and the quality of relationships Leaders and employees as a variable mediation

The type of data used is quantitative and qualitative data. Source of data sourced from primary data and secondary data, with sampling with saturated sampling technique or census, kuisoner counted 132 employees of BCA Regional Office Madiun, Data analysis technique with PLS Structural Equation Model (SEM) result of this research, Organizational Justice have significant effect to the quality of leader and employee relationships, Organizational Justice has a significant effect on the behavior of Organizational membership, Range of control has a significant effect on the quality of leader relationships, Range of control significant effect on Organizational membership behavior, Quality relationship leader and employees significantly influence Organizational citizen behavior.

Copy Right, IJAR, 2017,. All rights reserved.

\section{Introduction:-}

Background:-

Competition is at the core of the success or failure of an organization in such a competitive situation, an uncompetitive organization will gradually withdraw from competition, loss of consumers, and will soon go out of business. While companies that have competitiveness will be superior and able to survive. According to Ishak and Alam, (2009) in a journal entitled The Effects of Leader-Member Exchange on Organizational Justice and 
Organizational Citizenship Behavior, many factors that exist within an organization are involved and need attention. Factors such as financial factors, technology, information systems, production equipment, natural resources, and human resources (Isaac and Nature, 2009: 324-334). In a company or organization, human beings are valuable assets, which can have a significant impact on achieving organizational goals. The relationship of leaders and employees is seen as an important factor in discussing the phenomenon of leadership. The importance of human role in determining the success of an institution, both private sector institutions and the public sector with its ability to create value based on its people, not through the use of natural and technological resources, is more concerned with the quality of work of its human resources (Greenberg, J. and Baron, RA, 2003: 162). The rationale for the Leader member exchange (LMX) theory is that within the work unit, the supervisor develops a different type of relationship with the employee.

Organizational Citizenship Behavior (OCB) is important to support the effectiveness of organizational functions, especially in the long term. According to Podsakoff et al., (2000: 513-563). The results of Isaac and Nature (2009: 324-334) show that OCB will materialize if there is organizational justice and the effect of organizational justice will be greater on OCB through the quality of leader and employee relations (Leader member exchange, LMX), A high organizational structure with a narrow range of controls allows for closer personal control and contact between managers and employees. However, the risk of a narrow range of controls is that managers know only a few employees, so span of control variables can be novel in OCB-related research.

\section{Organizational Behavior Theory:-}

Robbins (2005: 32-47) argues that organizational behavior is a way of thinking that examines the behavioral impacts of individuals, groups, and organizational structures that aim to gain knowledge in developing organizational effectiveness. Gibson (1996) defines organizational behavior as a field of study that includes theories, methods, and principles from different disciplines to study individual perceptions, values, individual learner capacities, and actions while working in groups and in organizations as a whole, analyzing the impact of the external environment on the organization and its resources, mission goals and strategies.

\section{Organizational Justice:-}

Attention to justice has risen significantly in the social sciences of the last three decades. Colquitt, et al., (2001: 425445) posits three models of justice: distributive justice, procedural justice, and interactional justice.

Distributive Justice is justice about outcomes, such as comparing between one's own income to another's income, to aspects of one's income, or to one's income deemed appropriate by another standard used as a reference (Blau,2004: 567)

Procedural justice is first studied in conjunction with procedural aspects, such as the appropriateness and consistency of the application of the procedure, or the rewards shown to the individual as the subject of the Colquitt procedure (2001: 384-400). When a procedure feels fair, the individual will react more positively to income than to feel unfair. A fair process is very important because it will satisfy people to be involved even if their income is not satisfactory (Elovainio, et al, 2005: 271-274).

Interactional Justice is defined as the accepted interpersonal treatment under applicable procedures (Elovainio, et al., 2005: 271-274). Interactional Justice develops when decision makers treat people with respect, sensitivity and explain rational decisions entirely (Colquitt, 2001: 384-400).

\section{Span of control:-}

The department is an activity to organize the organizational units to be assigned to certain work areas or functions. The goal is for the work to run smoothly and efficiently through groupings by type and relationship. The principle of span of control requires that the exact person should be under the control of the leadership so that supervision is possible. This is important because it involves the effectiveness of the control of the group members.

\section{Quality of Leaders and Employee Relations (LMX):-}

Schriesheim; Castro et al. (in Johnson, 2009: 365-379) states that the main concept of a member exchange leader focuses on the quality of the exchange of relationships. This is in line with what Graen (in Ping \& Yue, 2010: 4445), defines the leader member exchange as an exchange of interpersonal relationships between employees and their leaders. 
Theoretical Thinking Framework:-

Based on previous theories and research, the theoretical framework can be formulated as follows:

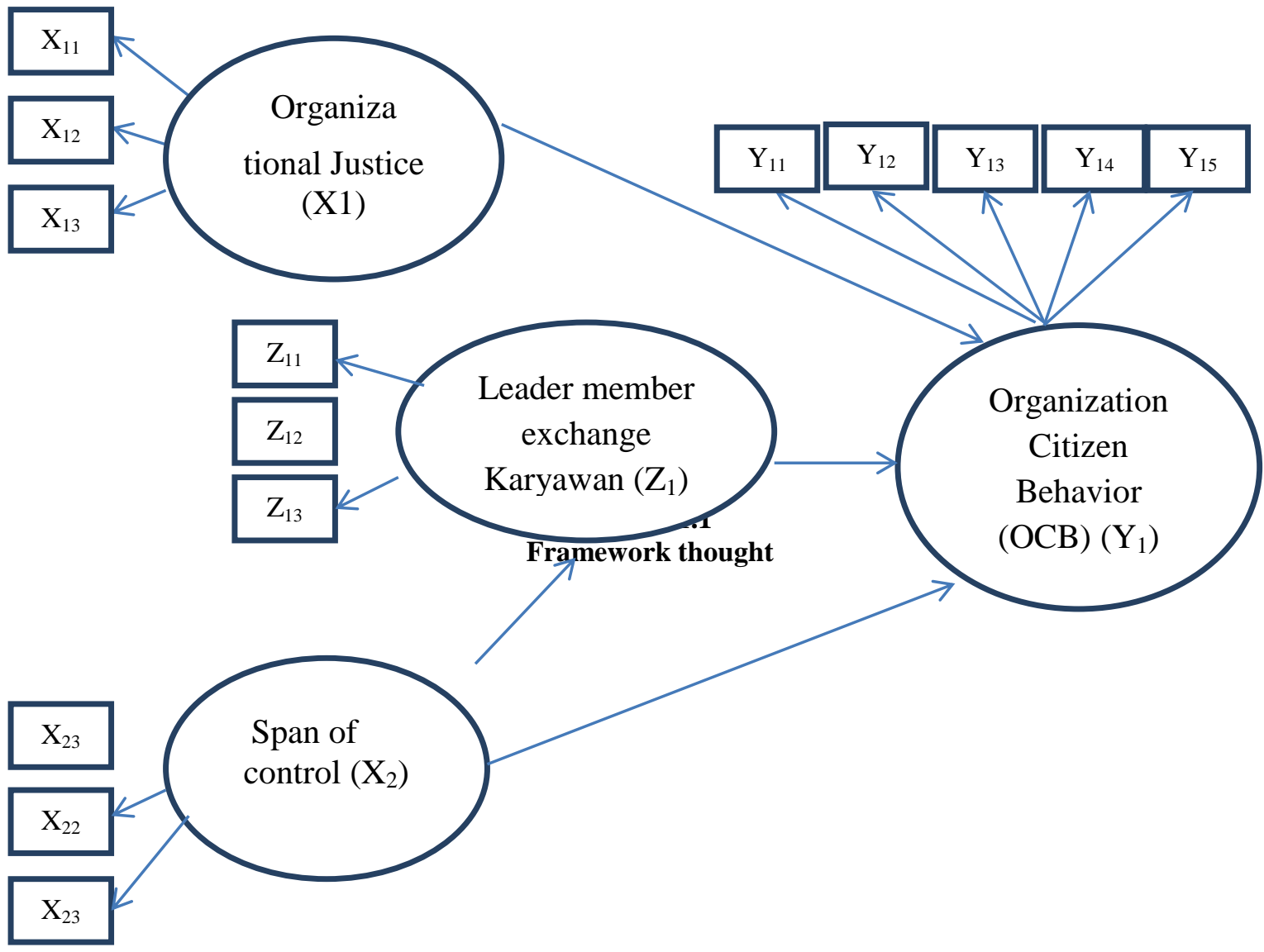

H1: Organizational Justice has a significant effect on the quality of leader and employee relationship (LMX) employee of BCA Bank Regional Office Madiun (Rizka Nugraha Pratikna, 2015)

$\mathrm{H} 2$ : Organizational justice has a significant effect on organizational membership behavior (OCB) employee of BCA Regional Office Madiun Bank (Crospanzano, et al., 2003)

H3: Range of control significantly affects the quality of leader and employee relationship (LMX) employee of BCA Bank Regional Office Madiun (Anna Partina, 2015)

H4: Control span has significant effect on organizational membership behavior (OCB) of BCA Regional Office Madiun (Crospanzano, et al., 2003)

H5: The quality of leader and employee relationship (LMX) has a significant effect on the organization's membership behavior (OCB) of BCA Regional Office Madiun (Noormala Amir Ishak and Syed Shah Alam, 2009)

his research is explanatory research. The design used is the survey design that is the research that takes samples from one population and use the questionnaire as the main data collection tool. The population in this research are all employees of BCA Regional Office Madiun and BCA Bank KCP Caruban, Magetan, Ponorogo, Ngawi and BCA Jl H.Agus salim Madiun from executive level until supervisor of 132 people.

Table 1.1 :- Operational Definition of Research Variables:-

\begin{tabular}{|l|l|l|}
\hline \multicolumn{1}{|c|}{ Variables } & \multicolumn{1}{c|}{ Indicator } & \multicolumn{1}{c|}{ Item Pernyataan } \\
\hline The Item & Organizational Justice & 1) The salary received is no different from a friend \\
Statement Item & (X1) (Colquitt, et al, & $\begin{array}{l}\text { work that level } \\
\text { Variable }\end{array}$ \\
$\begin{array}{l}\text { 2001) Justice } \\
\text { Variables }\end{array}$ & $\begin{array}{l}\text { 2) Work is proportional to the rewards received } \\
\text { Independe n }\end{array}$ & $\begin{array}{l}\text { 3) The rewards given by the company in accordance with the } \\
\text { contribution to the organization }\end{array}$ \\
\hline
\end{tabular}




\begin{tabular}{|c|c|c|}
\hline & & $\begin{array}{l}\text { 4) The reward received is proportional to the resulting } \\
\text { performance }\end{array}$ \\
\hline & $\begin{array}{l}\text { Justice } \\
\text { procedural } \\
(\mathrm{X} 12)\end{array}$ & $\begin{array}{l}\text { 5) Company rules apply to all } \\
\text { employees } \\
\text { 6) Supervision of employees is done without taking sides } \\
\text { 7) Leaders have consistency in the application of regulations }\end{array}$ \\
\hline & $\begin{array}{l}\text { Justice } \\
\text { Interactional } \\
(\mathrm{X} 13)\end{array}$ & $\begin{array}{l}\text { 8) The leadership gives a good example in } \\
\text { work } \\
\text { 9) Leaders appreciate employee performance } \\
\text { 10) Leaders respect differences of opinion with employees }\end{array}$ \\
\hline \multirow[t]{3}{*}{$\begin{array}{l}\text { Span of } \\
\text { control }(\mathrm{X} 2)\end{array}$} & $\begin{array}{l}\text { Task Properties } \\
\text { (X21) }\end{array}$ & $\begin{array}{l}\text { 1) Supervision performs its function well } \\
\text { 2) Each section has supervision that controls employee } \\
\text { performance } \\
\text { Ability }\end{array}$ \\
\hline & $\begin{array}{l}\text { Ability } \\
\text { Employees } \\
(\mathrm{X} 22)\end{array}$ & $\begin{array}{l}\text { 3) High work experience is not } \\
\text { require high supervision } \\
\text { 4) New employees need to be supervised in their work }\end{array}$ \\
\hline & $\begin{array}{l}\text { Contacts and } \\
\text { Coordination } \\
(\mathrm{X} 23)\end{array}$ & $\begin{array}{l}\text { 5) Coordination with fellow sections must be running effective } \\
\text { 6) Coordination with the inter-part must be effective }\end{array}$ \\
\hline $\begin{array}{l}\text { Variables } \\
\text { Intervening }\end{array}$ & Affection (Z11) 1) & 1) The leader is favored as someone who personality \\
\hline Variables & indicator & Item Statement \\
\hline \multirow{4}{*}{$\begin{array}{l}\text { Leader member } \\
\text { exchange }(\mathrm{Z} 1) \\
\text { (Dionne, } \\
\text { 2000) }\end{array}$} & affection (Z11) & $\begin{array}{l}\text { 1) The leader is favored as someone who is } \\
\text { personality } \\
\text { 2) Leaders can be good friends } \\
\text { 3) Employees love to work with leaders }\end{array}$ \\
\hline & loyalty $(\mathrm{Z} 12)$ & $\begin{array}{l}\text { 4) Leaders maintain employee decisions } \\
\text { 5) The leadership protects the disputing employees } \\
\text { 6) Leaders protect employees who make mistakes }\end{array}$ \\
\hline & Contribution(Z13) & $\begin{array}{l}\text { 7) Employees provide support and energy } \\
\text { on the leadership } \\
\text { 8) Employees strive to assist leaders in achieving job goals } \\
\text { 9) Employees do not think about the hard work being done for } \\
\quad \text { the leadership } \\
\text { Respect }\end{array}$ \\
\hline & $\begin{array}{l}\text { Respect Professional } \\
(\mathrm{Z} 14)\end{array}$ & $\begin{array}{l}\text { 10) Employees are impressed with knowledge } \\
\text { leader } \\
\text { 11) Employees appreciate leadership skills } \\
\text { 12) Employees are impressed with the leadership skills }\end{array}$ \\
\hline \multirow[t]{5}{*}{$\begin{array}{l}\text { Variables } \\
\text { Dependent } \\
\text { Organizatio n } \\
\text { Citizen Behavior } \\
\text { (OCB) }\end{array}$} & Altruistic (Y11) & $\begin{array}{l}\text { 1) Assist new employee orientation process } \\
\text { 2) Doing other people's tasks when peers are not logged in } \\
\text { 3) Helping others outside the department when they have } \\
\text { problems } \\
\text { 6) Make use of time to work }\end{array}$ \\
\hline & $\begin{array}{l}\text { Conscientiousn } \\
\text { ess (Y12) }\end{array}$ & $\begin{array}{l}\text { 4) Arrive early } \\
\text { 5) On time every day } \\
\text { 6) Make use of time to work }\end{array}$ \\
\hline & $\begin{array}{l}\text { sportmanship } \\
\text { (Y13) }\end{array}$ & $\begin{array}{l}\text { 7) Not many demanding work facilities } \\
\text { 8) No complain against work } \\
\text { 9) It does not matter to the welfare of the organization. }\end{array}$ \\
\hline & Courtesy (Y14) & $\begin{array}{l}\text { 10) Maintain an organization image } \\
\text { 11) Maintain an attitude within the organization. } \\
\text { 12) Avoiding conflict with fellow co-workers }\end{array}$ \\
\hline & virtue & 13) Pleased to engage in organizational activities \\
\hline
\end{tabular}



$\left(\mathrm{Y}_{15}\right)$
14) Attend events organized by the organization
15) Volunteer to organize organizational committees

\section{Data analysis:-}

Convergent validity:-

Convergent validity of measurement models with reflective indicators (indicators seen as effects of observable / measured constants) is judged by correlation between item score / component score estimated with Soft PLS. Individual reflective sizes are said to be high if they correlate more than 0.70 with measured constructs. However, according to Chin, 1998 (in Ghozali, 2006) for the initial stages of development the scale of measuring the loading values of 0.5 to 0.6 is considered sufficient.

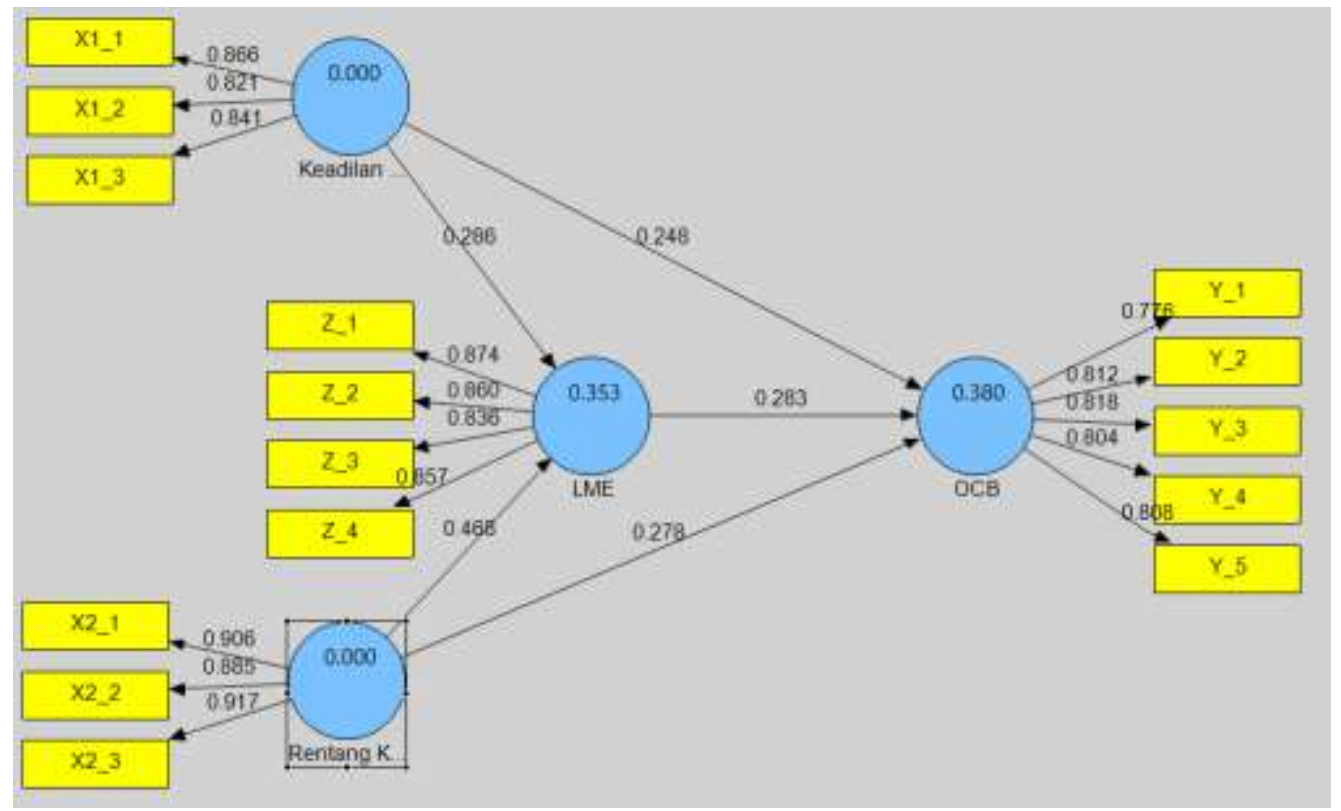

Based on Figure 4.1 can be explained outer loading of the model of organizational justice variables, span of control, leader member exchange (LME) and Organization Citizen Behavior (OCB) with SmartPLS program as follows:

Table 1.2:- Testing Validity by Using Loading Factor

\begin{tabular}{|c|c|c|c|c|c|}
\hline Kode Item & $\begin{array}{c}\text { Weights or } \\
\text { Loadings }\end{array}$ & Information & Item Code & $\begin{array}{c}\text { Weights } \text { or } \\
\text { Loadings }\end{array}$ & Information \\
\hline X1_1 & 0.866475 & Valid & Z_3 & 0.836291 & Valid \\
\hline X1_2 & 0.821055 & Valid & Z_4 & 0.857051 & Valid \\
\hline X1_3 & 0.840537 & Valid & Y_1 & 0.775955 & Valid \\
\hline X2_1 & 0.906404 & Valid & Y_2 & 0.811873 & Valid \\
\hline X2_2 & 0.885301 & Valid & Y_3 & 0.817895 & Valid \\
\hline X2_3 & 0.917474 & Valid & Y_4 & 0.803851 & Valid \\
\hline Z_1 & 0.874216 & Valid & Y_5 & 0.808066 & Valid \\
\hline Z_2 & 0.859864 & Valid & & & \\
\hline
\end{tabular}

Discriminant Validity:-

Table 1.3:- Nilai Discriminant Validity (Cross Loading)

\begin{tabular}{|l|c|c|c|c|}
\hline & Organizational Justice & LME & OCB & $\begin{array}{c}\text { Span of } \\
\text { control }\end{array}$ \\
\hline X1_1 & 0.866475 & 0.321531 & 0.304872 & 0.103573 \\
\hline X1_2 & 0.821055 & 0.320032 & 0.316534 & 0.123972 \\
\hline X1_3 & 0.840537 & 0.310207 & 0.402057 & 0.246259 \\
\hline X2_1 & 0.164336 & 0.441852 & 0.392176 & 0.906404 \\
\hline
\end{tabular}




\begin{tabular}{|c|c|c|c|c|}
\hline X2_2 & 0.132367 & 0.456029 & 0.384736 & 0.885301 \\
\hline X2_3 & 0.215799 & 0.513357 & 0.493186 & 0.917474 \\
\hline Y_1 & 0.330644 & 0.387103 & 0.775955 & 0.331974 \\
\hline Y_2 & 0.348632 & 0.393815 & 0.811873 & 0.267178 \\
\hline Y_3 & 0.414956 & 0.459134 & 0.817895 & 0.374036 \\
\hline Y_4 & 0.302121 & 0.443523 & 0.803851 & 0.433734 \\
\hline Y_5 & 0.239098 & 0.402091 & 0.808066 & 0.477371 \\
\hline Z_1 & 0.368052 & 0.874216 & 0.487110 & 0.490793 \\
\hline Z_2 & 0.284929 & 0.859864 & 0.464645 & 0.469872 \\
\hline Z_3 & 0.278865 & 0.836291 & 0.376528 & 0.384066 \\
\hline Z_4 & 0.348862 & 0.857051 & 0.446465 & 0.437576 \\
\hline
\end{tabular}

From Table 1.3 it can be seen that some loading factor values for each indicator of each latent variable still have the largest loading factor value compared to the loading value if associated with other latent variables. This means that any latent variable has good discriminant validity.

Composite Reliability dan Average Variance Extracted:-

Table 1.4:- Composite Reliability dan Average Variance Extracted

\begin{tabular}{|l|c|c|}
\hline \multicolumn{1}{|c|}{ Variables } & Composite Reliability & $A V E$ \\
\hline Organizationl justice & 0.880355 & 0.710471 \\
\hline Span of control & 0.929945 & 0.815695 \\
\hline Leader member exchange (LME) & 0.917058 & 0.734385 \\
\hline Organization Citizen Behavior $(\mathrm{OCB})$ & 0.901147 & 0.645868 \\
\hline
\end{tabular}

Based on Table 1.4 it can be concluded that all constructs meet reliable criteria. This is indicated by the value of composite reliability above 0.70 as the recommended criteria. The AVE value for each construct has an AVE value above 0.50 , meaning that all variables have a high and good composite reliability value.

\section{Goodness of fit model PLS:-}

Table 1.5:- Nilai R-Square

\begin{tabular}{|l|c|}
\hline \multicolumn{1}{|c|}{ Variables } & $\mathrm{R}^{2}$ \\
\hline Leader member exchange (LME) & 0,3528 \\
\hline Organization Citizen Behavior $(\mathrm{OCB})$ & 0,3800 \\
\hline
\end{tabular}

\section{Structural Model Testing (Inner Model):-}

Inner model or structural model testing is done to see the relationship between constructs through significance value or hypothesis test. The significance of estimated parameters provides very useful information on the relationship between research variables.

Table 1.6:- The Direct Influence of Constructs Research

\begin{tabular}{|l|c|c|c|c|}
\hline \multicolumn{1}{|c|}{ construct } & $\begin{array}{c}\text { weighting } \\
\text { influence }\end{array}$ & T Statistics & T Critical & Information \\
\hline $\begin{array}{l}\text { organizational justice } \rightarrow \text { quality of leader and } \\
\text { employee relations (LMX) }\end{array}$ & 0,286 & 2,851 & 1,96 & Significant \\
\hline $\begin{array}{l}\text { organizational justice } \rightarrow \text { organizational } \\
\text { membership behavior (OCB) }\end{array}$ & 0,248 & 2,086 & 1,96 & Significant \\
\hline $\begin{array}{l}\text { Span of control } \rightarrow \text { Quality of leader and } \\
\text { employee relationship (LMX) }\end{array}$ & 0,468 & 6,694 & 1,96 & Significant \\
\hline $\begin{array}{l}\text { Span of control } \rightarrow \text { organizational membership } \\
\text { behavior (OCB) }\end{array}$ & 0,277 & 2,540 & 1,96 & Significant \\
\hline $\begin{array}{l}\text { Quality relationships of leaders and employees } \\
\text { (LMX) } \rightarrow \text { organizational membership behavior } \\
(\text { OCB) }\end{array}$ & 0,282 & 2,302 & 1,96 & Significant \\
\hline
\end{tabular}

The test results with bootstrapping from PLS analysis are as follows: 


\begin{abstract}
Hypothesis testing 1:-
Organizational justice has a significant effect on the quality of leader and employee relationship (LMX) employee of BCA Bank Regional Office Madiun The results of the first hypothesis test show that the effect of organizational justice variable on leader and employee relationship (LMX) shows the value of path coefficient of 0.286 with the value of Tstatistik equal to 2,851. $\mathrm{T}$ statistic value is greater than $\mathrm{T}$ table $(1,960)$. This result means that organizational justice has a positive and significant influence on the quality of leader and employee relationship (LMX) employee of BCA Bank Regional Office Madiun, meaning the first hypothesis in this research is accepted.
\end{abstract}

\title{
Testing hypothesis 2:-
}

Organizational justice has a significant effect on organizational membership behavior (OCB) employee of BCA Bank Regional Office Madiun ,The result of the second hypothesis test shows that the effect of organizational justice variable on organizational membership behavior (OCB) shows the coefficient value of 0,248 with the value of Tstatistik equal to 2,086. Tstatistic value is greater than Ttable $(1,960)$. This result means that organizational justice has a positive and significant influence on organizational membership behavior (OCB) employee of BCA Bank Regional Office Madiun, meaning the second hypothesis in this research is accepted.

Testing hypothesis 3:- Range of control significant effect on the quality of leader and employee relationship (LMX) employees of BCA Bank Regional Office Madiun,The result of the first hypothesis test shows that the influence of the control range variable on the leader and employee relationship (LMX) shows the value of path coefficient of 0.468 with the Tstatistic value of 6.694 . Tstatistic value is greater than Ttable $(1,960)$. This result means that the span of control has a positive and significant influence on the quality of leader and employee relationship (LMX) employee of BCA Regional Office Madiun, meaning the third hypothesis in this study is accepted.

Testing hypothesis 4: Range of control significant effect on organizational membership behavior (OCB) employee of BCA Bank Regional Office Madiun, The result of the fourth hypothesis test shows that the influence of the control range variable on the organization's membership behavior (OCB) shows the coefficient value of 0.277 with the value of Tstatistik 2,540. Tstatistic value is greater than Ttable $(1,960)$. This result means that the span of control has a positive and significant influence on the organization's organizational membership (OCB) behavior of BCA Regional Office Madiun Bank, meaning the fourth hypothesis in this study is accepted.

\section{Hypothesis testing 5:-}

The quality of leader and employee relationship (LMX) has a significant effect on organizational membership behavior (OCB) employee of BCA Bank Regional Office Madiun,The result of the fifth hypothesis test shows that the influence of quality variable of leader and employee relationship (LMX) to organizational membership behavior (OCB) shows coefficient value of lane equal to 0,282 with value of $T$ statistik equal to 2,302. Tstatistic value is greater than $\mathrm{T}$ table $(1,960)$. This result means that the quality of leader and employee relationship (LMX) has a positive and significant influence on the organization's membership behavior (OCB) of BCA Regional Office Madiun employees, meaning the fifth hypothesis in this research is accepted.

\section{Conclusion:-}

Based on the results of analysis and hypothesis testing that has been done, as well as the objectives to be achieved from the research, it can be concluded as follows:

1. Organizational Justice has a significant effect on the quality of leader and employee relationship of BCA Bank Regional Office Madiun, thus if Organizational Justice can run well, it will improve the quality of leader and employee relationship of BCA Bank Regional Office Madiun (supporting Pratikna research, 2015) .

2. Organizational Justice has a significant effect on organizational membership behavior of BCA Bank Regional Office Madiun employees, thus, although organizational justice can run well, it will not have a big impact on membership behavior of BCA Bank Regional Office Madiun (supporting Isaac and Nature research, 2009) .

3. Range of control significantly influence the quality of leader and employee relationship of BCA Bank Regional Office Madiun employees, thus if the span of good control, it can improve the quality of leader and employee relationship of employees of BCA Bank Regional Office Madiun (supporting Pratikna research, 2015).

4. The control span has significant effect on the membership behavior of the employees of BCA Bank Regional Office Madiun, so if the span of control is going well, it will improve the organizational membership behavior of BCA Bank Regional Office Madiun employees (supporting Jaya research, 2015).

5. The quality of leader and employee relationship has a significant effect on organizational membership behavior of BCA Bank Regional Office Madiun employees. Thus, if the relationship between leader and employee is 
qualified, it will improve the organizational membership behavior of BCA Bank Regional Office Madiun (supporting Kurniawati research, 2010).

\section{Suggestion:-}

The research conclusions described in the previous chapter provide information for the researcher to provide the following suggestions:

To the BCA Regional Office Madiun Bank in terms of human resource management, it is expected:

1. Improving organizational justice for employees, especially through interactional justice, by way of leadership should often give good examples to employees, leaders appreciate employees who perform well, and leaders must respect any differences of opinion submitted by employees at the time of meeting.

2. Improve the characteristics of the task, especially through the autonomy of employees, that is by giving the opportunity by the leadership so that employees can perform the task in accordance with their own way, the leader gives more freedom to the employees to be more independent in carrying out their duties, and the leader should often provide opportunities for employees to be independent in thinking and acting in his daily duties.

3. Fixed the span of control primarily through the nature of the tasks of employees, that is by way of performing supervision functions more effectively, and pay attention to the parts that are still overlapping in running supervision, so that employee performance control is still not effective.

4. Improving the quality of relationships between leaders and employees primarily through increased employee loyalty, that is by way of leadership must be able to maintain employee decisions, able to protect employees who disputes, and able to protect employees who make mistakes so that employees can bangkin from mistakes and able to perform better.

5. Strengthening Organizational commitment of employees especially through affective commitment, that is by giving support and spirit of leadership to employees in order to carry out their duties based on leadership experience, increase the influence of leadership to employees, and employee control process is not only based on the figures of mere performance measurement, but must also use a psychological approach.

6. Increasing the reflection of high organizational membership behavior for every employee, especially through courtesy, that is by increasing the willingness of employees to always maintain Organizational image, reducing the potential for conflict between employees with colleagues.

7. Further research is needed on other variables that also influence Organizational membership behavior outside the variables studied in order to improve the model developed in this research that is by adding the motivation variable (Ibrahim and Salinda, 2014) and variable

\section{References:-}

1. Blau, P. M., 2004, Exchange and Power in Social Life. New York: John Wiley.P.567

2. Carlos, M.P. \& Filipe, C., 2011, From personal values to creativity: evidence from frontline service employees, European Journal of Marketing, 45 (7/8), p. 1029-1050

3. Colquitt, J. A., 2001, On the dimensionality of organizational justice: A construct validation of a measure, Journal of Applied Psychology, 86, p. 384-400.

4. Colquitt, J. A., Conlon, D. E., Wesson, M. J., Porter, O. L. H., dan Ng. KY.,

5. 2001, Justice at the millenium: A meta-analytic review of 25 years of organizational research, Journal of Applied Psychology, Vol.86, p. 425-445.

6. Elovainio M, Leino-Arjas P, Vahtera J, Kivimäki M., 2005, Justice at work and cardiovascular mortality prospective cohort study, Journal Psychosomatic Reserch, Vol. 61: p. 271-274.

7. Gibson, Ivancevich, Donnelly, 1996, Organisasi, Perilaku, Struktur, Proses, Bina Rupa Aksara, Jakarta.

8. Greenberg, J. and Baron, R.A., 2003, Behavior in Organizations. $9^{\text {th }}$ ed. Pearson

9. Prentice Hall. Upper Saddle River, New Jersey. p. 774

10. Harris, K.J., Andrews M.C., Kacmar K.M., 2007, The moderating effects of justice on the relationship between organizational politics and workplace attitudes, Journal of Bussiness Psychology. P. 22:135-144.

11. Ishak, Noormala Amir and Alam, Syed Shah, 2009, The Effects of Leader- Member Exchange on Organizational Justice and Organizational Citizenship Behavior: Empirical Study European Journal of Social Sciences, Vol. 8, No. 2, p. 324-334

12. Jaya, Nenet Natasudian, 2015, Meningkatkan Perilaku Ekstra Peran Karyawan. Jurnal GaneÇ Swara,Vol. 9 No.1 Maret 2015, h. 163-166

13. Johnson, D. W., \& Johnson, R. T., 2009, An educational psychology success story:Social interdependence 
theory and cooperative learning. Educational Researcher, 38(5), p. 365-379.

14. Kurniawati, 2010, Pengaruh Leader-member Exchange pada Organizational Citizenship Behavior dengan Kepercayaan dan Dukungan Supervisor sebagai Variables Pemediasi, Fakultas Ekonomi Universitas Sebelas Maret Surakarta

15. Masterson, S. S., Lewis, K., Goldman, B. M., \& Taylor, M. S., 2000, Integrating justice and social exchange: The differing effects of fair procedures and treatment on work relationships, Academy of Management Journal, 43, p.738-748.

16. Partina, Anna, 2015, Keterkaitan Ketidakamanan Kerja (Job Insecurity) Dengan Social Exchange Model, Jurnal Kinerja, Volume 16, No.1, Th. 2012: Hal.13-28

17. Ping, Fong Siu and Ho Ka Yue, 2010, The mediating Effects of Leader-Member Exchange (LMX) and Teammember exchange $(T M X)$ on the relationship between emotional intelligence,job satisfaction and job performance of the employees. Hong Kong Baptist University.

18. Posdakoff, P. S. MacKenzie, B. Paine, \& D. Bachrach, 2000, Organizational Citizenship Behavior: A critical review of the theoretical and empirical literature and suggestions for future research, Journal of Management, Vol. 26, No.3, p. 513-563.

19. Pratikna, Rizka Nugraha, 2015, Leader-Member Exchange Sebagai Pemoderator Dalam Pengaruh Kepemimpinan Transformasional Terhadap Persepsi Tentang Rasa Keadilan Organisasional, Jurnal Bina Ekonomi, Volume 19 Nomor 2, 2015, h. 105-114

20. Robbins, S., 2005, Organizational Behavior, New Jersey: Prentice Hall.

21. Sekaran, Uma, 2006, Metodologi Penelitian Untuk Bisnis, Edisi 4. Penerbit Salemba Empat, hal 74-79

22. Supranto, J. 2000, Teknik Sampling untuk Survei dan Eksperimen, Jakarta:Rineka Cipta. 